\title{
Analysis of the mortality rate for tumors in the central nervous system between 1979 to 2018 in the State of Piauí, Brazil
}

\author{
Análise da taxa de mortalidade por tumores no sistema nervoso central entre 1979 a 2018 no \\ Estado do Piauí, Brasil
}

Análisis de la tasa de mortalidad por tumores en el sistema nervioso central entre 1979 y 2018 en el

Estado de Piauí, Brasil

Received: 12/16/2020 | Reviewed: 12/23/2020 | Accept: 12/27/2020 | Published: 01/02/202

\author{
Danielle dos Santos Araújo \\ ORCID: https://orcid.org/0000-0002-2387-0207 \\ Centro Universitário do Piauí, Brazil \\ E-mail: dannyswan2011@hotmail.com \\ Emmanuel Alves Soares \\ ORCID: https://orcid.org/0000-0003-3742-1362 \\ Centro Universitário do Piaú, Brazil \\ E-mail: eas.fisio@hotmail.com \\ Wanderson Lopes dos Santos Freitas \\ ORCID: https://orcid.org/0000-0002-2900-5492 \\ Universidade Federal do Maranhão, Brazil \\ E-mail: wandersonlopez15@gmail.com \\ Maurício dos Santos Araújo \\ ORCID: https://orcid.org/0000-0002-7728-2590 \\ Universidade Federal de Viçosa, Brazil \\ E-mail: mauricio.araujo@ufv.br
}

\begin{abstract}
The brain and spinal cord constitute the central nervous system (CNS). The number of cases of death by tumor in the CNS has been growing in Brazil. However, knowledge of the incidence of the mortality rate in the State of Piauí is still incipient. The aim of the study was to investigate the pattern of the mortality rate from tumors of the central nervous system in the State of Piauí, Brazil, between 1979 to 2018. The data on mortality in the CNS in the State of Piauí, between the years 1979 to 2018 was obtained in the database of the Informatics Department of the Brazilian Unified Health System by the Mortality Information System. Linear regression analysis was used to assess the trend in the mortality rate. All analyzes were performed in the Computational and Statistical Environment R. Between 1979 to 2018 there was an increasing increase in the mortality rate of $0.13 \%$ in men and $0.11 \%$ in women. The mortality rate tends to increase over the years $\left(\mathrm{R}^{2}=0.62 ; \mathrm{p}<0.01\right)$, as observed by simple linear regression analysis. The cities with the highest mortality rate were Passagem Franca do Piauí, São Luís do Piauí, Barro Duro do Piauí and Angical do Piauí. Therefore, the study can provide subsidies for the formulation of measures to prevent this disease in places with a high mortality rate.
\end{abstract}

Keywords: Glioma; Mortality; Neoplasia.

\section{Resumo}

O cérebro e a medula espinhal constituem o sistema nervoso central (SNC). O número de casos de morte por tumor no SNC vêm crescendo no Brasil. Entretanto, o conhecimento da incidência da taxa de mortalidade no Estado do Piauí ainda é incipiente. O objetivo do estudo foi investigar o padrão da taxa de mortalidade por tumores do sistema nervoso central no Estado do Piauí, Brasil, entre 1979 a 2018. Os dados de mortalidade no SNC no Estado do Piauí, entre os anos de 1979 a 2018 foi obtido na base de dados do Departamento de Informática do Sistema Único de Saúde do Brasil pelo Sistema de Informação de Mortalidade. A análise de regressão linear foi usada para avaliar a tendência na taxa de mortalidade. Todas as análises foram feitas no Ambiente Computacional e Estatístico R. Entre 1979 a 2018 houve um aumento crescente na taxa de mortalidade de $0,13 \%$ em homens e $0,11 \%$ em mulheres. A taxa de mortalidade tende em aumentar ao longo dos anos $\left(\mathrm{R}^{2}=0,62 ; \mathrm{p}<0,01\right)$, observado pela análise de regressão linear simples. As cidades com a maior taxa de mortalidade foram Passagem Franca do Piauí, São Luís do Piauí, Barro Duro do Piauí e Angical do Piauí. Portanto, o estudo pode fornecer subsídios para a formulação de medidas de prevenção dessa doença em locais com alta taxa de mortalidade.

Palavras-chave: Glioma; Mortalidade; Neoplasia. 


\begin{abstract}
Resumen
El cerebro y la médula espinal constituyen el sistema nervioso central (SNC). El número de casos de muerte por tumor en el SNC ha ido creciendo en Brasil. Sin embargo, el conocimiento de la incidencia de la tasa de mortalidad en el estado de Piauí es aún incipiente. El objetivo del estudio fue investigar el patrón de la tasa de mortalidad por tumores del sistema nervioso central en el estado de Piauí, Brasil, entre 1979 y 2018. Los datos de mortalidad en el SNC en el estado de Piauí, entre los años 1979 a 2018 se obtuvo en la base de datos del Departamento de Informática del Sistema Único de Salud de Brasil por el Sistema de Información de Mortalidad. Se utilizó un análisis de regresión lineal para evaluar la tendencia de la tasa de mortalidad. Todos los análisis se realizaron en el Entorno Computacional y Estadístico R. Entre 1979 y 2018 hubo un aumento creciente en la tasa de mortalidad del 0,13\% en hombres y del 0,11\% en mujeres. La tasa de mortalidad tiende a aumentar a lo largo de los años $\left(\mathrm{R}^{2}=0,62 ; \mathrm{p}<0,01\right)$, como se observa en el análisis de regresión lineal simple. Las ciudades con mayor tasa de mortalidad fueron Passagem Franca do Piauí, São Luís do Piauí, Barro Duro do Piauí y Angical do Piauí. Por lo tanto, el estudio puede otorgar subsidios para la formulación de medidas para prevenir esta enfermedad en lugares con una alta tasa de mortalidad.
\end{abstract}

Palabras clave: Glioma; Mortalidad; Neoplasia.

\title{
1. Introduction
}

Tumors of the central nervous system (CNS) are considered pathologies of an idiopathic character that make up a differentiated group of variable conduct neoplasms and histology (Rodrigues, et al., 2014). A high number of cases of CNS tumors occur in developing countries (Dolecek ta, et al., 2012). This tumor is the second leading cause of mortality in children in Brazil (Gasparini, et al., 2013). Between 2009 to 2013, there was an increase in the number of deaths by $0.41 \%$, representing 1.4 to $1.8 \%$ of all malignant tumors in the world, $88 \%$ only in the CNS (DATASUS, 2014).

Cancer is the second leading cause of death in the world, responsible for 9.6 million deaths in 2018. The incidence of these deaths is related to the way of life. It is estimated that $70 \%$ of deaths affect the population in underdeveloped countries (WHO, 2018). Central nervous system tumors are divided into two groups: the primary ones (when their cell birth comes from brain tissue) and the secondary (when they originate from other organs - metastasis) (Ribeiro Junior, et al., 2012).

The causes of CNS tumors are still unknown. However, it is believed that the potential source of this disease is due to genetic and environmental causes. The individual's exposure to chemical compounds and radiation can contribute to the development of these tumors. Studies have focused on the possible causes and risk factors related to these diseases, but none has been proven so far (Gurney \& Kadan-Lottick, 2017).

The CNS tumor is the second cause of death in less than 20 years, from 2001 to 2007. In 2009, deaths from this group of tumors accounted for $20 \%$ of deaths from cancer in the country. Data on the growth of mortality from CNS tumors in children and adolescents in the literature are still scarce (Gasparini, et al., 2013).

Tumors in the CNS occupy the ninth position of prevalence in men and the eighth in women in the Northeast region of Brazil (Sandes, 2020). Most tumors originate in the brain, meninges, and cranial nerves (Goodenberger \& Jenkins, 2012). The treatment is complex and involves several health professionals such as a physiotherapist, nutritionists, speech therapists, and nurses. Between the period 2008 to $2013,57,361$ procedures were performed for the treatment of tumors in the CNS, and the Northeast region occupied the second place with a number of 18\% for these surgeries (Pontes, 2017).

Studies that aimed to assess the behavior of the CNS mortality rate in Brazilian States are excessive. Our paper is the first research that describes the distribution of the mortality rate of this tumor in the State of Piauí, which may support research in the area of public health. This article aimed to investigate the pattern of the mortality rate for tumors in the CNS behaves in the State of Piauí, Brazil from 1979 to 2018, observing the mortality rates of these tumors by age group in all cities of Piauí and determining the spatial distribution of these rates. 


\section{Material and Methods}

\subsection{Characterization of study}

This was documentary research with a quantitative approach. The documentary research uses techniques of apprehension, understanding, and analysis of documents of the most varied types (Fávero \& Centenaro, 2019). Data were collected in the database of the Informatics Department of the Brazilian Unified Health System, through the Atlas SUS corresponding to the number of deaths from tumors in the CNS in the State of Piauí, Brazil between the years 1979 to 2018 (Figure 1).

Figure 1. Map with the geographical delimitations of the State of Piauí, Brazil.

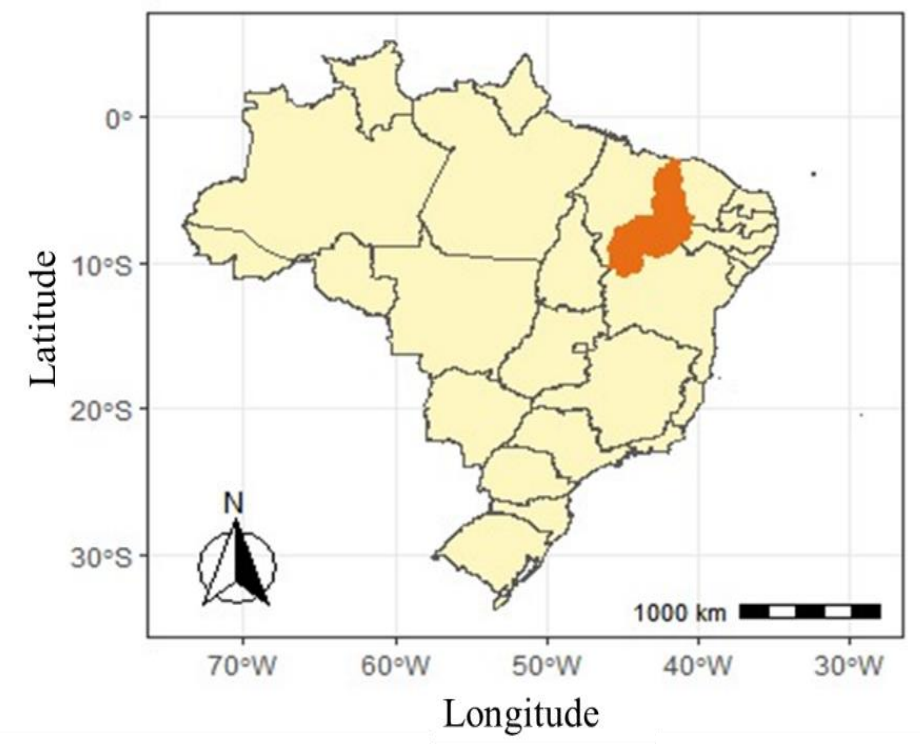

Source: Authors.

\subsection{Data collection}

The raw data were collected in the Atlas SUS online database of cancer mortality, available in DATASUS. The data were stratified by sex and age group. Crude and adjusted mortality rates were calculated by age for sex. The reason for the analysis during the period from 1979 to 2018 was due to the availability of data in this database.

\subsection{Trend analysis}

The spatial distribution of the mortality rate used the shapes of the 224 municipalities that make up the State of Piauí. These tools were obtained free of charge via the Instituto Brasileiro de Geografia e Estatística. Spatial analysis of area was determined by the spatial ecological unit of Piauí municipalities.

The data were processed using the QGis software (version 3.10.1). This tool allows the manipulation of vector and matrix data for the use and management of thematic bases. The map of mortality rates for tumors in the CNS was grouped into quantiles, in shape file format consisting of three files with extensions shp, shx and dbf with Universal Transverse Mercator (UTM) projection with the regional geodetic system for South American Datum (SAD 69).

\subsection{Statistical analysis}

The specific mortality rate was age-standardized using the direct method, considering the world standard population proposed by Segi (1960) with adaptations by Doll, Payne, and Waterhouse (1966). The significance of the temporal trend was 
assessed by simple linear regression (In $\left.(y)=\beta_{0}+\beta_{1} x\right)$, in which the logarithms of mortality rate standardized by the Brazilian population in 2010. The mortality rate was considered the dependent variable and the years studied as an independent variable. All analyzes were performed in the Computational and Statistical Environment R (R Core Team, 2020).

\section{Results}

The mortality rate from tumors in the CNS increased during the years 1979 to 2018 in Piauí. Simple linear regression analysis showed a significant increase $(\mathrm{p}<0.01)$ in cases of death in that period, in other words, the increase in the mortality rate tends to increase over the years, with a determination coefficient $\left(\mathrm{R}^{2}\right)$ : 0.62. During the years 1979 to 1984 , mortality levels remained stable. The number of deaths reached zero between the years 1985 to 1992. Mortality rates in the following years increased dramatically. The temporal analysis between, 1993 to 2000 showed a gradual development of the rates corresponding to $0.31 \%$ of deaths in 1996. However, differently from previous periods, the rates remained stable between, 2000 to 2002. However, after that time there was a decline of $0.13 \%$ in 2004. In the following years, mortality rates maintained a trend, reaching $0.19 \%$ in 2009 (Figure 2).

Figure 2. Proportional distribution of total deaths from cancer of central nervous system according to the years 1979 to 2018 , Piauí, Brazil.

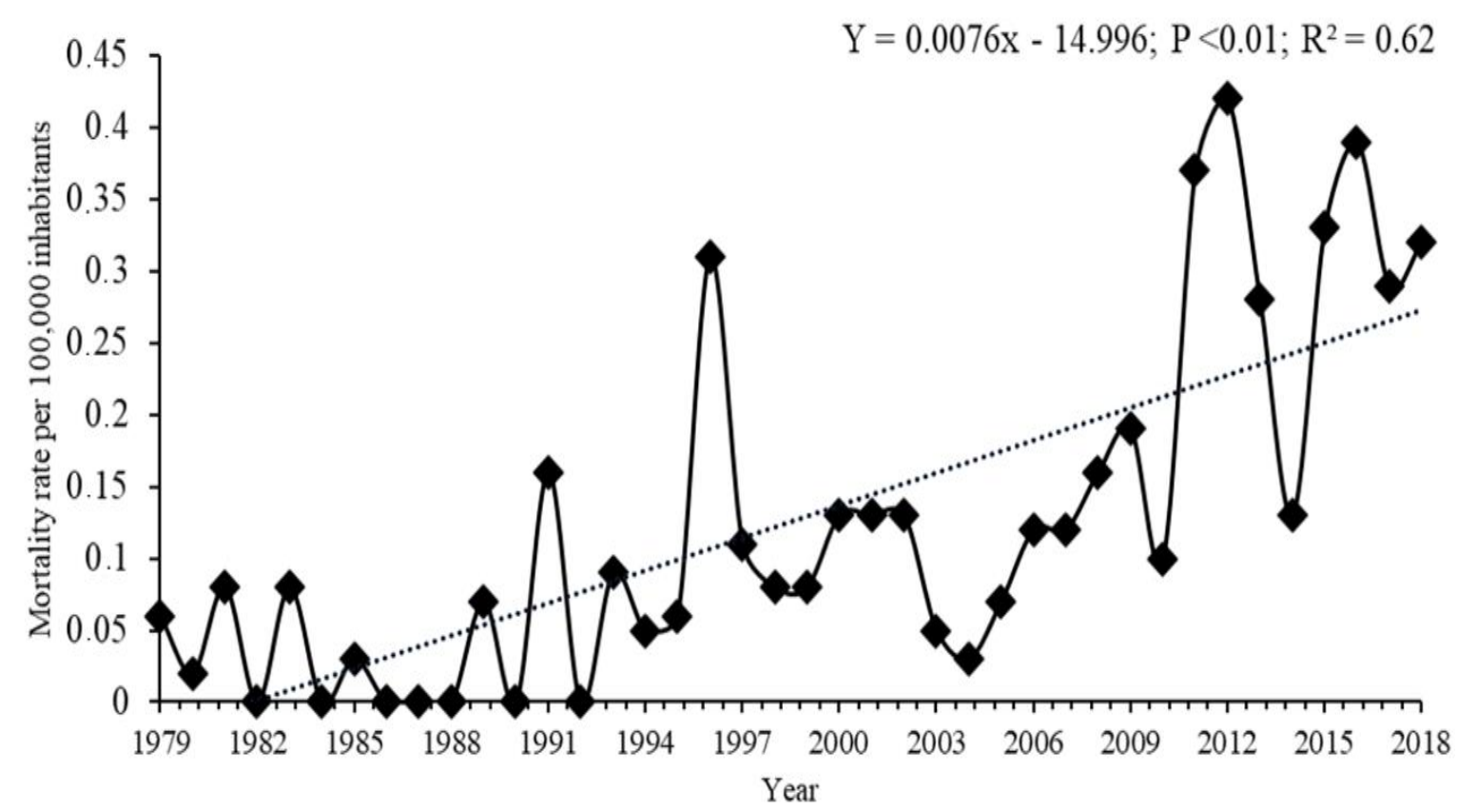

Source: Authors.

A high level of mortality was verified between, 2011 to 2018. The mortality rate exceeded the trend line of the analysis carried out, equivalent to about $0.42 \%$ in 2012 . This period was considered the highest mortality rate in Piauí in relation to Brazil. In 2017 , there was a decrease in the death rate corresponding to $0.29 \%$, however, it remained above the trend line (Figure 2).

The male sex had the highest number of deaths in all age groups analyzed, corresponding to $0.13 \%$ of the cases recorded over the years. The number of deaths was 68 in the State of Piauí. However, female sex increased with a gross rate of $0.11 \%$, corresponding to 64 deaths (Table 1). 
Table 1. The crude and adjusted rate for tumors in the central nervous system, stratified by sex based on the Brazilian population of 100,000 in the State of Piauí between, 1979 to 2018.

\begin{tabular}{|c|c|c|c|c|c|}
\hline \multicolumn{2}{|l|}{ Men } & \multicolumn{2}{|c|}{ Women } & \multicolumn{2}{|l|}{ Total } \\
\hline $\begin{array}{c}\text { Number of } \\
\text { deaths }\end{array}$ & Specific rate & $\begin{array}{c}\text { Number of } \\
\text { deaths }\end{array}$ & Specific rate & $\begin{array}{c}\text { Number of } \\
\text { deaths }\end{array}$ & Specific rate \\
\hline 4 & 0.06 & 4 & 0.06 & 8 & 0.06 \\
\hline 2 & 0.03 & 1 & 0.02 & 3 & 0.02 \\
\hline 3 & 0.05 & 2 & 0.03 & 5 & 0.04 \\
\hline 4 & 0.07 & 2 & 0.03 & 6 & 0.05 \\
\hline 6 & 0.07 & 0 & 0.00 & 6 & 0.03 \\
\hline 6 & 0.09 & 6 & 0.08 & 12 & 0.08 \\
\hline 5 & 0.10 & 7 & 0.13 & 12 & 0.11 \\
\hline 14 & 0.39 & 17 & 0.43 & 31 & 0.41 \\
\hline 14 & 0.60 & 14 & 0.53 & 28 & 0.56 \\
\hline 4 & 0.32 & 8 & 0.54 & 12 & 0.44 \\
\hline 6 & 1.35 & 3 & 0.49 & 9 & 0.85 \\
\hline 68 & - & 64 & - & 132 & - \\
\hline
\end{tabular}

Source: Authors.

The mortality rate in children and adolescents has decreased over the years. Individuals between, 50 to 69 years old had a high mortality rate compared to other ages. Declines in the mortality rate in the elderly population over 70 to 80 years old were equivalent to individuals aged 30 to 49 years old (Figure 3 ).

Figure 3. Crude and adjusted cancer mortality rate in the central nervous system stratified by age per 100,000 men and women in the State of Piauí between, 1979 to 2018.

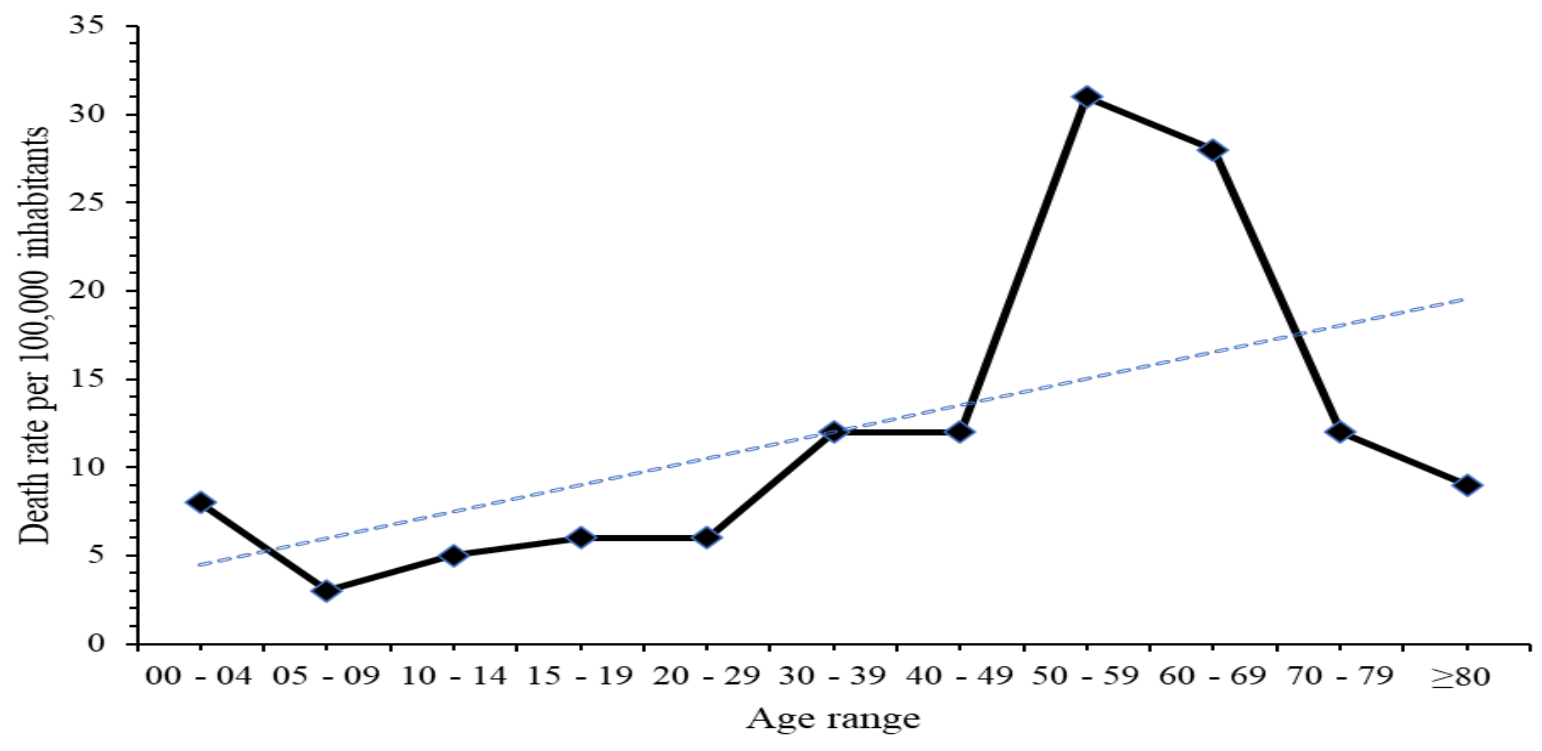

Source: Authors.

The spatial distribution analysis of the CNS tumor mortality rate was identified in the following municipalities: Passagem Franca do Piauí, São Luís do Piauí, Barro Duro and Angical do Piauí (Figure 4). 
Figure 4. Map of spatial distribution referring to the State of Piauí and distributions of its municipalities with mortality rates by municipality.

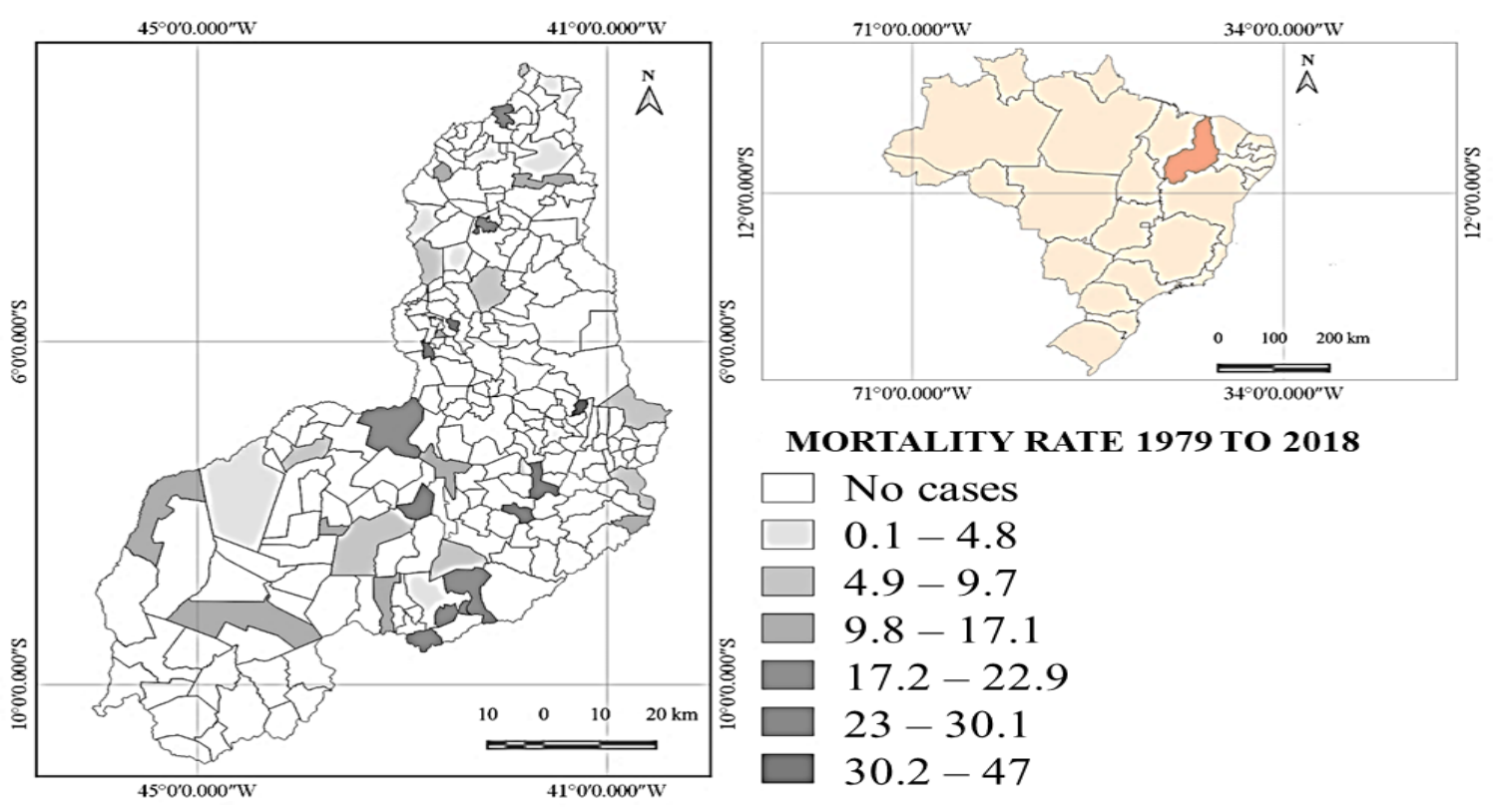

DATUM: SIRGAS, 2000

Cartographic base: Instituto Brasileiro de Geografia e Estatística

Database : Sistema de Informação sobre Mortalidade - SIM

Elaboration: Authors

Teresina, December 15, 2020

Source: Authors.

\section{Discussion}

During the years 1984 to 1988 the mortality rate from CNS tumors in men reached zero. In women, on the other hand, there was a decrease in these neoplasms. Therefore, this fact can be explained by an improvement in the socio-economic conditions and in the lives of individuals in some municipalities in the State of Piauí. In a similar study in American cities, it was concluded that there is a strong correlation between income indicators and socio-economic conditions (household income and health insurance) with brain tumors that tend to increase more slowly. However, they suffered a decrease during these years (Inskip, et al., 2003). In Italy, the incidence of CNS tumors in adult individuals increased between 1986 and 1997. However, this result was not statistically significant. The mortality rate decreased during this period, with a higher prevalence in men than in women (Crocetti, et al., 2004).

Regarding the analysis of the mortality rate by sex, there was an increase in men $(0.13 \%)$ during these years. The mortality rate by age showed that this tumor had a higher prevalence in individuals between 50 to 69 years old. This fact is confirmed in a study of the last five-year period (2005-2009), which observed higher mortality rates in males in all age groups analyzed, except that of 10-14 years in which they suffered a reduction (Gittleman, et al., 2017). These data differ from a study that showed mortality from brain tumors in the State of Rio de Janeiro, Brazil, in the years 1980 to 1998, with an increase, specifically in the elderly. The rate standardized by the world population increased from 2.24 / 100,000 in 1980 to 3.35 / 100,000 in 1998. This can be explained due to the progress in the technological environment and the advances in the means of diagnostic imaging (Gasparini, et al., 2013).

In Goiânia between, 1988 to 1997, the mortality rates due to tumors in the CNS increased for males, with an increase of 0.51. For females, the rates remained constant during the years analyzed (Latorre, 2001). The analysis made by sex showed 
that these tumors remained oscillating during the studied periods. However, during the years studied (1979 to 2018 ) men remained with higher mortality rates.

In a similar study carried out in the Brazilian Amazon between 1997 to 2014, it concluded that the incidence of CNS tumors did not show significant differences between men and women (Carvalho, et al., 2017). However, the incidence ratio between sexes varies greatly according to the geographic area, the age group, and the histological type of the tumor. The prevalence of males in gliomas, which represent $75 \%$ of malignant neoplasms of the CNS, suggests that hormonal reasons may be involved in the etiology of these tumors (Huang, et al., 2004). This information may justify the increase in deaths in men in some municipalities in Piauí for some years.

The lower number of CNS tumor mortality cases in women may be due to continuous monitoring, unlike males. Men in general do not follow up with health professionals, compared to women (Sant, et al., 2011). Based on the data analyzed, over the years it was possible to observe that the female gender was not frequently affected by this neoplasm. For some years, the female sex had an increase in the mortality rate in relation to the male. This fact can be explained due to the exposure of women in workplaces, and the use of chemicals such as cosmetics, especially in young individuals (Gasparini, et al., 2013). Based on this information, it can be said that explanatory factors are likely for the growth observed in the standardized female mortality rate from CNS tumors. A second hypothesis to explain the increase in cases is the improvement in detection due to technological advances and access to diagnostic methods, such as magnetic resonance and computed tomography. This fact also contributed to the evolution in treatment (Raaschou Nielsen, et al., 2006).

Related to age, in the State of Piauí CNS tumors reduced in children aged 0 to 4 years during the period evaluated by the research. However, individuals between 50 to 69 years old have a high mortality rate in relation to other ages. In the State of Rio de Janeiro, CNS neoplasms in children and adolescents suffered a decrease of $1.5 \%$ per year between 1980 to 2009 (Gasparini, et al., 2013). Based on these data, it was possible to verify that the information between the municipalities coincides, that is, this type of pathology does not affect children with a higher prevalence, as in adult individuals.

A study that analyzed the period from 1985 to 1999 in the United States of America (USA), showed that mortality from CNS tumors increased dramatically in the elderly during the years studied and reduced in young individuals (Hoffman, et al., 2006). Another study also conducted in the USA, found that the relative survival in the elderly in 5 years is lower than in young people with these tumors. Survival for this pathology is directly linked to the age of the individual and the histological type of the tumor (Wrensch, et al., 2002). This information differs from the results found in the present study, in which the CNS tumors related to age group were verified in the State of Piauí. This neoplasm was reduced in elderly people over 70 years old with rates equivalent to individuals the aged 30 to 49 years, that is, it did not present an increase in this group. A possible hypothesis for this fact was the improvement of sophisticated diagnostic techniques, changes in attitude towards the elderly (lifestyle, food) and easier access to medical care. However, it does not reflect an increase in risk.

Standardized rates of incidence and mortality from brain tumors tend to be higher in underdeveloped countries and represent the 12th death rate in men (Ferlay, et al., 2013). The incidence of CNS tumors has important geographic variability (Fisher, et al., 2007). In this sense, it can be observed that in the State capital (Teresina), the gross rates were extremely lower in relation to the municipalities presented, corresponding to $6.19 \%$ during the period studied (1979 to 2018). However, unlike the municipalities that stood out, it was observed that in all year's deaths from these neoplasms occurred in the capital. However, in the highlighted municipalities, the rates remained to fluctuate over the years, that is, a high number of deaths were present in just one year, or more. However, it can be concluded that in the selected cities with the highest mortality rates in Piauí, there was no increase in all years, unlike the State capital, which has kept growing throughout the studied period. 


\section{Final Considerations}

The increase in mortality from CNS tumors was greater in men aged 50 to 69 years. The monitoring of the tumor mortality rate in the CNS is indicative of the changes that have occurred in the country. However, the work can expand the available information and provide subsidies for the formulation of hypotheses to be investigated in the future.

\section{References}

Brasil. (2020). Resolução $n^{o}$ 510, de 7 de abril de 2016. https://bvsms.saude.gov.br/bvs/saudelegis/cns/2016/re s0510_07_04_2016.html\#: :text=considerando\%20a\%20import\%c3\%a2ncia\%20de\%20se,art

Carvalho, L. E. W., Sarraf, J. S., Semblano, A. A. P., Moreira, M. A., Lemos, M. N., Mello, V. J., Hamoy, M., Junior, M. H. N., Junior, F. M. P., \& Adami, F. (2017). Central nervous system tumours profile at a referral center in the Brazilian Amazon region, 1997-2014. Plos One, 12(4), 174-439.

Crocetti, E., Capocaccia, R., Casella, C., Guzzinati, S., Ferretti, S., Rosso, S., Sacchettini, C., Spitale, A., Stracci, F., \& Tumino, R. (2004). Casella Populationbased incidence and mortality cancer trends (1986-1997) from the network of Italian cancer registries. European Journal of Cancer Prevention, 13(4), 287-295.

DATASUS. (2020). Distribuição proporcional do total de mortes por câncer, segundo localização primária do tumor, por sexo, localidade, por período selecionado. 2014. https://mortalidade.inca.go v.br/MortalidadeWeb/pages/Modelo02/consultar.xhtml\#panelResultado.

Dolecek, T. A., Propp, J. M., Stroup, N. E., \& Kruchko, C. (2012). CBTRUS statistical report: primary brain and central nervous system tumors diagnosed in the United States in 2005-2009. Neuro Oncology, 1(5), 646-647.

Fávero, A. A., \& Centenaro, J. B. (2019). A pesquisa documental nas investigações de políticas educacionais: potencialidades e limites. Revista Contrapontos, $19(1), 170-184$.

Ferlay, J., Steliarova-Foucher, E., Lortet-Tieulent, J., Rosso, S., Coebergh, J. W. W., Comber, H., Forman, D., \& Bray, F. (2013). Cancer incidence and mortality patterns in Europe: estimates for 40 countries in 2012. European Journal of Cancer, 49(6), 1374-1403.

Fisher, J. L., Schwartzbaum, J. A., Wrensch, M., \& Wiemels, J. L. (2007). Epidemiology of brain tumors. Neurologic Clinics, United States, 25(4), 867-890.

Gasparini, B., Monteiro, G. T. R., \& Koifman, S. (2013). Mortalidade por tumores do sistema nervoso central em crianças e adolescentes no Rio de Janeiro, Brasil, 1980-2009. Caderno de Saúde Coletiva, 21(3), 272-280.

Gittleman, H., Kromer, C., Ostrom, Q. T., Blanda, R., Russell, J., Kruchko, C., \& Barnholtz-Sloan, J. S. (2017). Is mortality due to primary malignant brain and other central nervous system tumors decreasing?. Journal Neurooncol, 133(2), 265-275.

Goodenberger, M. L., \& Jenkins, R. B. (2012). Genetics of adult glioma. Cancer Genetics, 205(12), 613-621.

Gurney, J. G., \& Kadan-Lottick, N. (2001). Brain and other central nervous system tumors: rates, trends, and epidemiology. Current Opinion in Oncology, 13(3), $160-166$.

Hoffman, S., Propp, J. M., \& Mccarthy, B. J. (2006). Temporal trends in incidence of primary brain tumors in the United States, 1985-1999. Neuro Oncology, Charlottesville, 8(1), 27-37.

Huang, K., Whelan, E. A., Ruder, A. M., Ward, E. M., Deddens, J. A., Davis-king, K. E., Carreón, T., Waters, M. A., Butler, M. A., Calvert, G. M., Schulte, P. A., Zivkovich, Z., Heineman, E. F., Mandel, J. S., Morton, R. F., Reding, D. J., \& Rosenman, K. D. (2004). Reproductive factors and risk of gliomas in women. Cancer Epidemiol Biomark Prev, 10(13), 1583-1588.

INCA - Instituto Nacional de Câncer. (2020). Câncer do sistema nervoso central. https://www.inca.gov.br/tipos-de-cancer/cancer-do-sistema-nervoso-central.

Inskip, P. D., Tarone, R. E., Hatch, E. E., Wilcosky, T. C.,Fine, H. A., Black, P. M., Loeffler, J. S., Shapiro, W. R., Selker, R. G., \& Linet, M. S. (2003). Sociodemographic and risk of brain tumours. International Journal of Epidemiology, 32(2), 225-233.

Latorre, M. R. D. O. (2001). Câncer em Goiânia: análise da incidência e da mortalidade no período de 1988 a 1997. Revista Brasileira de Epidemiologia, 4(3), $145-152$.

Pontes, L., Sthefaee, M. N., Haaland, B., \& Lopes, G. (2017). Surgery for CNS Tumors in the Brazilian National Health Care System. Journal of Global Oncology, 3(2), 157-161.

R Development Core Team (2020). R: A language and environment for statistical computing. R Foundation for Statistical Computing, Vienna, Austria.

Raaschou Nielsen, O., Sorensen, M., Carstensen, H., Jensen, T., Bernhardtsen, T., Gjerris, F., \& Schmiegelow, K. (2006). Increasing incidence of childhood tumours of the central nervous system in Denmark, 1980-1996. British Journal of Cancer, 95(3), 416-422.

Ribeiro Junior, N. G. R., Gomes, R. M., Guerra-Junior, A. A., \& Acurcio, F. A. (2012). Eficácia e segurança de temozolamida no tratamento de astrocitoma de baixo grau. Retrieved, December 22, 2020, from https://sites.bvsalud.org/redetsa/brisa/resource/?id=biblioref.referencesource.879457.

Rodrigues, D. B., Lima, L. O., Pereira, E. L., Souza, U. O., Oliveira, M. F., Moura-Lima, A., \& Rotta, J. M. (2014). Epidemiologia das neoplasias intracranianas no hospital do servidor público estadual de São Paulo: 2010-2012. Arquivo Brasileiro de Neurocirurgia, 33(1), 6-12.

Sandes, V. A., Dantas, R. L., Porto, R. L. S., Reis, F. F. P., Sousa, D. S., Lima, S. O., Marcena, S. L. S., \& Reis, F. P. (2020). A ocorrência de tumores do sistema nervoso central no estado de Sergipe no período de 2008 a 2017. Research, Society and Development, 9(11), 343-391. 
Research, Society and Development, v.10, n. 1, e2510111269, 2021

(CC BY 4.0) | ISSN 2525-3409 | DOI: http://dx.doi.org/10.33448/rsd-v10i1.11269

Sant, M., Minicozzi, P., Lagorio, S., Johannesen, T. B., Marcos-Gragera, R., \& Francisci, S. (2011). Survival of European patients with central nervous system tumors. International Journal of Cancer, 131(1), 173-185.

WHO. World Health Organization. (2018) Cancer. https://www.who.int/news-room/fact-sheets/detail/cancer.

Wrensch, M., Minn, Y., Chew, T., Bondy, M., \& Berger, M. S. (2002). Epidemiology of primary brain tumors: current concepts and review of the literature. Neuro Oncology, 4(4), 278-299. 